\title{
MEASURING ANTI-ROMA PREJUDICE IN SLOVAKIA: INTRODUCTION TO THE MONOTHEMATIC SYMPOSIUM ${ }^{1}$
}

\author{
BARBARA LÁŠTICOVÁ
}

In this monothematic symposium we discuss the challenges we faced when developing measures of stereotypes and anti-Roma prejudice for use in Slovakia. Developing these measures was the first step in an ongoing research project where the aim is to test the effectiveness of direct and indirect contact interventions in reducing prejudice against stigmatized minorities in Slovakia, particularly the Roma. Slovakia is a central European country with a substantial Roma minority that is estimated by experts to represent $7.45 \%$ of total population (Mušinka, Škobla, Hurrle, Matlovičová, \& Kling, 2014), making Roma the second largest ethnic minority after the Hungarian minority.

The INTERMIN ${ }^{2}$ project discussed in this symposium brings together researchers from various disciplines (social psychology dominates) with different methodological backgrounds, including practitioners from human rights non-governmental organizations (NGOs). All of us have previously been involved in several research projects on intergroup relations and stereotypes, mainly concerning relations with other national and ethnic groups (Graf, Hřebíčková, Petrjánošová, \& Leix, 2015; Lášticová \& Petrjánošová, 2014; Drál, Galanská, \& Návojský, 2014; Findor, 2011; Kanovský, 2009). These projects adopted either qualitative or mixed research methods, and not all of them were solely academic in purpose.

However, for most of us this is the first time we attempt to combine theory-driven academic research with an effort to experimentally test the effectiveness of contact

\footnotetext{
${ }^{1}$ This work was supported by the Slovak Research and Development Agency under contract no. APVV14-0531.

${ }^{2}$ INTERMIN is the abbreviated title of the following project - "Interventions for Reducing Prejudice against Stigmatized Minorities: Developing measures and experimental testing of the contact hypothesis under field conditions.” The members of the research team are Barbara Lášticová (principal investigator), Magda Petrjánošová, Simona Andraščiková (all from the Institute for Research in Social Communication, Slovak Academy of Sciences), Andrej Findor, Martin Kanovský, Miroslav Popper, Peter Drál (all from the Faculty of Social and Economic Sciences, Comenius University in Bratislava), and Miroslav Sirota from the University of Essex, UK.
}

(C) Institute for Research in Social Communication, Slovak Academy of Sciences 
interventions that could reduce prejudice outside the lab. While Slovak academic researchers have so far focused predominantly on measuring the content and strength of endorsements of particular stereotypes and prejudiced views without trying to change them in the field, the prejudice reduction interventions have mainly been carried out by NGOs, and there was no accompanying systematic and rigorous assessment of the effectiveness of these interventions (see Drál \& Findor, 2016, this issue). In INTERMIN we attempt to bridge this gap and focus on anti-Roma prejudice reduction in schools, a particularly sensitive area in this respect (Drál \& Findor, 2016; Lášticová \& Findor, 2016 this issue). The interventions will be informed by recent research on direct and indirect intergroup contact (Miles \& Crisp, 2014; Pettigrew \& Tropp, 2016; Vezzali et al., 2015).

The first major problem with a research endeavour of this nature arises in relation to measuring the impact of the interventions. Standardized instruments for measuring explicit and implicit prejudice, which would allow for international comparison and test the effectiveness of the interventions, have yet to be developed in Slovak. The second problem concerns the risk that the interventions will fail to reduce anti-Roma prejudice in Slovak schools, since Slovak Roma face substantial levels of prejudice, discrimination and social exclusion in different areas of social life (Vašečka, 2002; European Commission, 2015), including schools (Drál' \& Findor, 2016 this issue).

The monothematic symposium in this issue explores primarily the first problem: measuring stereotypes of and prejudice against the Roma. In the project explicit and implicit measures of prejudice and stereotypes are used; however, in the symposium the focus is on explicit measures, since these have already been piloted in Slovakia and we are therefore able to discuss the difficulties that emerged during development, adaptation, and piloting. We have had to deal with a number of epistemological and methodological questions: Do we know what we are measuring? Do the participants understand the questionnaire items in the same way we-the researchers-do? Are we not just essentializing the stigmatized minorities and reproducing stereotypes by the very act of measuring them? How can we ask questions about stereotypes and prejudice in a sensitive and responsible manner?

The three studies in this monothematic symposium tackle these questions from various perspectives: the conceptual choices the researchers have to make when adapting existing measuring instruments for another culture; the meanings and interpretations elicited by these measures in the participants; and the challenges practitioners face when assessing pupils' attitudes and addressing stereotypes and prejudice in schools. Hence, the three papers should be viewed as different facets of the state of the art of anti-Roma prejudice research in Slovakia.

In the first paper, "Developing explicit measures of stereotypes and anti-Roma prejudice in Slovakia: Conceptual and methodological challenges", Barbara Lášticová and Andrej Findor explore the existing attitudinal, emotional and behavioural measures of stereotypes and prejudice in social psychology. They also discuss the problems researchers face when adapting these measures for use in Slovakia generally, and schools specifically, and to measure the effect of interventions to reduce anti-Roma prejudice. They argue that although some social psychology researchers have begun to shift away from a common focus on prejudice reduction among historically advantaged majority groups, the main challenge in Slovakia is to verify whether traditional prejudice reduction interventions that have proved 
successful in other cultures and with outgroups other than Roma will be effective in reducing anti-Roma prejudice among the Slovak ethnic majority.

The second paper, "Do we know what we are asking? Individual and group cognitive interviews", by Miroslav Popper and Magda Petrjánošová, analyses the results of cognitive interviews and discussions conducted with Slovak university and high school students in order to improve the questionnaires for measuring stereotypes and anti-Roma prejudice. Cognitive interviewing is a method for pre-testing survey questions that is commonly used in sociological research. It looks at questions that may be difficult to understand or leave too much room for unintended subjective interpretation. The authors argue that if researchers use a questionnaire without first conducting cognitive interviews, they have only a very small degree of control over what they are "really asking"-what the participants understand when reading and answering the questions. They also show how two rounds of cognitive interviews (in addition to statistical analyses of scale reliability and factor structure) helped to improve problematic items in the questionnaires for measuring stereotypes of and prejudice against the Roma.

In their paper, "Teachers as researchers? Assessing the impact of pedagogical interventions on pupils' attitudes", Peter Drál' and Andrej Findor argue that there has been a limited amount of research into attitudes in Slovak primary and secondary schools in general, and of prejudice towards various minorities in particular, over the past 25 years. Moreover, out of all the studies targeting young people, none was conducted with the explicit goal of modifying the existing curricula or improving teachers' professional development. Although various institutions produce activity toolkits for dealing with stereotypes, prejudice and discrimination, only a few of them were preceded by research or a thorough needs analysis of the potential users. The paper analyses the lessons learned from an intervention assessing pupils' attitudes, carried out by the first author in conjunction with a Slovak NGO. The authors conclude that effective prejudice reduction cannot be implemented without systemic changes occurring in the curriculum, quality control, undergraduate training and teachers' continuous education or in the assessment of educational outcomes.

\section{References}

Drál, P., \& Findor, A. (2016). Teachers as researchers? Assessing the impact of pedagogical interventions on pupils' attitudes. Human Affairs, 26(3), 271-287.

Drál, P., Galanská, N., \& Návojský, A. (Eds.). (2014). Kvalita alebo kvantita? Zistovanie postojových zmien v globálnom vzdelávaní a multikultúrnej výchove [Quality or quantity? Measuring attitude change in global and multicultural education]. Bratislava: Nadácia Milana Šimečku.

Findor, A. (2011). Začiatky národných dejín [The beginnings of national history]. Bratislava: Kalligram.

Graf, S., Hřebíčková, M., Petrjánošová, M., \& Leix, A. (2015). Češi a jejich sousedé: meziskupinové postoje a kontakt ve střední Evropě [Czechs and their neighbours: Intergroup attitudes and contact in central Europe]. Praha: Academia.

Kanovský, M. (2009). Esencializmus a etnicita: sociálno-kognitívne vysvetlenie reprezentovania sociálnych skupín [Essentialism and ethnicity: Socio-cognitive explanations of representations of the social groups]. Sociologický časopis, 45, 345-368.

Lášticová, B., \& Findor, A. (2016). Developing explicit measures of stereotypes and anti-Roma prejudice in Slovakia: Conceptual and methodological challenges. Human Affairs, 26(3), 233-252. 
Lášticová, B., \& Petrjánošová, M. (2014). Social identities, societal change, and mental borders: identity construction strategies of young Slovaks commuting between Bratislava and Vienna. In T. Magioglou (Ed.), Culture and political psychology: A societal perspective (pp. 285-312). Charlotte: Information Age Publishing, Inc.

Miles, E., \& Crisp, R. (2014). A meta-analytic test of the imagined contact. Group Processes Intergroup Relations, 17(3), 3-26.

Mušinka, A., Škobla, D., Hurrle, J., Matlovičová, K., \& Kling, J. (2014). ATLAS rómskych komunít na Slovensku 2013 [Atlas of Roma communities in Slovakia 2013]. Bratislava: UNDP.

Pettigrew, T. F., \& Tropp, L. R. (2006). A meta-analytic test of intergroup contact theory. Journal of Personality and Social Psychology, 90, 751-83.

Popper, M., \& Petrjánošová, M. (2016). Do we know what we are asking? Individual and group cognitive interviews. Human Affairs, 26(3), 253-270.

European Commission (2015). Special Eurobarometer 437: Discrimination in the EU in 2015. Retrieved from: http://dx.doi.org/10.2838/325154

Vašečka, M. (2002). Vztah majority k Rómom [Relations between the majority and Roma]. In M. Vašečka (Ed.), Čačipen pal o Roma. Súhrnná správa o Rómoch na Slovensku (pp. 335-351). Bratislava: IVO.

Vezzali, L., Stathi, S., Giovannini, D., Capozza, D., \& Trifiletti, E. (2015). The greatest magic of Harry Potter: Reducing prejudice. Journal of Applied Social Psychology, 45, 105-121.

Institute for Research in Social Communication,

Slovak Academy of Sciences,

Dúbravská cesta 9

84104 Bratislava

Slovakia

E-mail: barbara.lasticova@savba.sk 